\title{
PERANCANGAN PERANGKAT LUNAK PENDAFTARAN DAN PENJADWALAN UJIAN SKRIPSI PADA FAKULTAS KEDOKTERAN UNIVERSITAS PALANGKA RAYA BERBASIS WEBSITE
}

\author{
Widiatry ${ }^{\mathrm{a}, 1, *}$ \\ ${ }^{a}$ Universitas Palangka Raya, Kampus Tunjung Nyaho Jalan Yos Sudarso, Palangka Raya, Kalimantan Tengah, Indonesia \\ widiatry@it.upr.ac.id* \\ * corresponding author
}

\section{ARTICLE INFO}

\section{Keywords}

"Registration and Scheduling"

Thesis

Waterfall

\section{ABSTRACT}

Thesis is a scientific essay that is required as part of academic education requirements. Thesis is arranged and maintained to achieve a bachelor's degree at a tertiary institution, done according to certain rules and procedures. Thesis registration at the Faculty of Medicine, University of Palangka Raya still uses a manual system, where the submission of titles is still using paper forms and students are asked to fill out a research registration form. Students must meet the P2M Section to submit a research title. Information about the seminar schedule is still posted on the bulletin board so students must come to campus to view seminar schedule information.

To overcome these problems, a study was made, namely Design of Software Registration and Scheduling of Thesis Examinations at the Faculty of Medicine, University of Palangka Raya Website Based with the stages of research divided into two stages, namely: (1) literature study and (2) software development by applying modified waterfall method which includes four steps namely system analysis, design, implementation and testing. For implementation using PHP in making program code and Mysql as a database to store data. Furthermore, software testing uses Blackbox testing.

This software has facilities to support the progress of the thesis process at the Faculty of Medicine, Palangka Raya University, namely: (1) Submission of Research Proposals, (2) Registration of Research Proposal Seminars and Registration of Thesis Exams, (3) Scheduling of Research Proposal Seminars and Scheduling Exams Thesis. Users of this software are twofold, namely the P2M and Student Sections. Based on the results of tests conducted on users, it can be seen that this software can run well.

\section{Pendahuluan}

Arti kata skripsi dalam Kamus Besar Bahasa Indonesia (KBBI) adalah sebagai karangan ilmiah yang diwajibkan sebagai bagian dari persyaratan pendidikan akademis. Skripsi disusun dan dipertahankan untuk mencapai gelar sarjana pada perguruan tinggi. Skripsi adalah suatu karya untuk menghasilkan ilmu pengetahuan atau sesuatu yang dapat di pertanggung jawabkan secara ilmiah dan di kerjakan menurut aturan dan tata cara tertentu. Berikut pengertian dan definisi skripsi menurut para ahli :

a. Skripsi adalah karya ilmiah yang membahas suatu masalah berdasarkan hasil penelitian. Biasanya disusun sebagai salah satu syarat mengikuti ujian sarjana. (Mohamad Ali: 1984).

b. Skripsi adalah bagian dari suatu karangan faktawi, jenis karangan khususnya mengenai suatu topik keilmiahan dan pada umumnya ditujukan pada sidang pembaca yang berkecimpung dalam bidang pengetahuan ilmiah yang bersangkutan (P. Westra : 1991). 
c. Skripsi adalah sebuah karangan ilmiah yang diwajibkan untuk mengikuti ujian di perguruan tinggi (Bambang Marhijanto : 1993).

d. Skripsi adalah karya ilmiah yang ditulis melalui kegiatan perencanaan, pelaksanaan, dan hasil penelitian ilmiah oleh mahasiswa jenjang program sarjana muda atau sarjana (Ahmad : 1999).

Pada Fakultas Kedokteran Universitas Palangka Raya, mahasiswa bisa mengambil skripsi jika telah memenuhi syarat menyelesaikan modul perkuliahan. Pendaftaran skripsi di Fakultas Kedokteran Universitas Palangka Raya masih menggunakan sistem manual, dimana pengajuan judul masih menggunakan form kertas dan mahasiswa diminta untuk mengisi formulir pendaftaran penelitian. Mahasiswa harus menemui Bagian P2M (Penelitian dan Pengabdian Masyarakat) untuk mengajukan judul penelitian. Informasi tentang jadwal seminar masih ditempel di papan pengumuman sehingga mahasiswa harus datang ke kampus untuk melihat informasi jadwal seminar.

Berdasarkan latar belakang yang telah disebutkan di atas maka Fakultas Kedokteran Universitas Palangka Raya dirasa perlu mengadakan perubahan dari sistem konvensional menjadi terkomputerisasi yaitu dengan menganalisis dan merancang suatu perangkat lunak berbasis website untuk pendaftaran dan penjadwalan skripsi. Sehingga dapat membantu Bagian P2M (Penelitian dan Pengabdian Masyarakat) untuk mengatur pengelolaan pendaftaran skripsi agar dapat membantu mahasiswa untuk mendaftar skripsi dan memperoleh informasi tentang jadwal seminar. Perangkat lunak ini dibuat menggunakan bahasa pemrograman PHP dan database MySQL [1].

Beberapa penelitian telah dilakukan sebelumnya oleh peneliti yang digunakan untuk menambah pengetahuan dalam menganalisis dan merancang perangkat lunak ini yaitu Analisis dan Desain Perangkat Lunak Generate File Akun Uang Kuliah Tunggal (UKT) Universitas Palangka Raya [2] dan Pengembangan Perangkat Lunak Generate File Data Kehadiran Pegawai Universitas Palangka Raya [3]. Rancang Bangun Website E-Learning SMAN 1 Palangka Raya [4] dan Sistem Informasi Geografis Mencari Rute Lokasi Travel Di Kota Palangka Raya Berbasis Website [5] yang dapat menambah pemahaman dalam menganalisis dan merancang suatu perangkat lunak berbasis website. Rancang Bangun Website untuk Memeriksa Plagiat E-Journal Fakultas Kedokteran Universitas Palangka Raya [6] dan Penerapan Algoritma Levenshtein Distance Untuk Pencarian Pada Sistem Informasi Perpustakaan Fakultas Kedokteran Universitas Palangka Raya [7] yang digunakan sebagai dasar pengetahuan dalam analisis dan perancangan perangkat lunak di lingkup Fakultas Kedokteran Universitas Palangka Raya.

\section{Metodologi Penelitian}

Dalam penelitian ini, tahapan penelitian dibagi menjadi dua tahap yaitu (1) studi pustaka dan (2) pengembangan perangkat lunak dengan menerapkan metode waterfall yang telah dimodifikasi yang meliputi empat langkah yaitu analisis sistem, desain, implementasi dan pengujian [8]. Untuk implementasi menggunakan PHP dalam membuat kode program dan Mysql sebagai database untuk menyimpan data. Selanjutnya pengujian perangkat lunak menggunakan Blackbox testing. [9][10]. Model yang digunakan merupakan suatu hasil dari siklus hidup pengembangan perangkat lunak [11]. Berikut ini penjelasan tahapan penelitiannya:

\subsection{Studi Pustaka}

Metode ini melakukan studi pustaka terhadap buku dan jurnal ilmiah sebagai pendukung dalam penelitian bagaimana membuat Analisis Dan Perancangan Perangkat Lunak Pendaftaran Dan Penjadwalan Ujian Skripsi Pada Fakultas Kedokteran Universitas Palangka Raya Berbasis Website.

\subsection{Analisis Sistem}

Proses pencarian kebutuhan difokuskan pada perangkat lunak pendaftaran dan penjadwalan ujian skripsi berbasis website untuk mengetahui sifat dari perangkat lunak yang akan dibuat. Pemodelan fungsional menggunakan Data Flow Diagram (DFD) dan pemodelan data menggunakan Entity Relationship Diagram (ERD) [12]. 


\subsection{Desain}

Proses ini digunakan untuk membuat blueprint perangkat lunak seperti perancangan basis data dan perancangan navigation tree.

\subsection{Implementasi}

Proses yang akan dilakukan yaitu pembuatan perangkat lunak sesuai dengan perancangan yang telah dilakukan pada tahap sebelumnya.

\subsection{Pengujian}

Proses pengujian akan dilakukan dengan metode Blackbox testing yang disertai dengan melakukan simulasi data. Pengujian Blackbox adalah pengujian aspek fundamental sistem tanpa memperhatikan struktur logika internal suatu perangkat lunak [13]. Metode ini digunakan untuk mengetahui apakah perangkat lunak berfungsi dengan benar.

\section{Hasil dan Pembahasan}

\subsection{Analisis Sistem}

Perangkat lunak yang diusulkan ini belum pernah digunakan di Fakultas Kedokteran Universitas Palangka Raya. Perangkat lunak ini memiliki fasilitas-fasilitas untuk mendukung proses berjalannya skripsi di Fakultas Kedokteran Universitas Palangka Raya, yaitu : (1) Pengajuan Usulan Penelitian, (2) Pendaftaran Seminar Usulan Penelitian dan Pendaftaran Ujian Skripsi, (3) Penjadwalan Seminar Usulan Penelitian (Proposal) dan Penjadwalan Ujian Skripsi. Pengguna pada perangkat lunak ini ada dua, yaitu Bagian P2M (Penelitian dan Pengabdian Masyarakat) dan Mahasiswa.

a. Bagian P2M

Bagian P2M sebagai admin memiliki hak akses untuk mengatur dan mengelola website secara keseluruhan. Bagian P2M dapat mengelola akun mahasiswa, mengelola data skripsi, setting pendaftaran, pendaftaran skripsi dan penjadwalan skripsi.

b. Mahasiswa

Mahasiswa memiliki hak akses diantaranya kelola profil, pengajuan usulan penelitian, pendaftaran seminar usulan penelitian, pendaftaran ujian skripsi, melihat informasi jadwal seminar usulan penelitian dan jadwal ujian skripsi.

Untuk pemodelan fungsional perangkat lunak ini menggunakan Data Flow Diagram (DFD), dimana langkah yang pertama adalah menggambarkan diagram konteks yang akan merepresentasikan lingkup alur kegiatan dari seluruh pengguna perangkat lunak, kemudian diikuti dengan DFD level satu yang merupakan dekomposisi dari diagram konteks. Diagram konteks ditunjukkan pada gambar 1, dan DFD level 1 ditunjukkan pada gambar 2. 


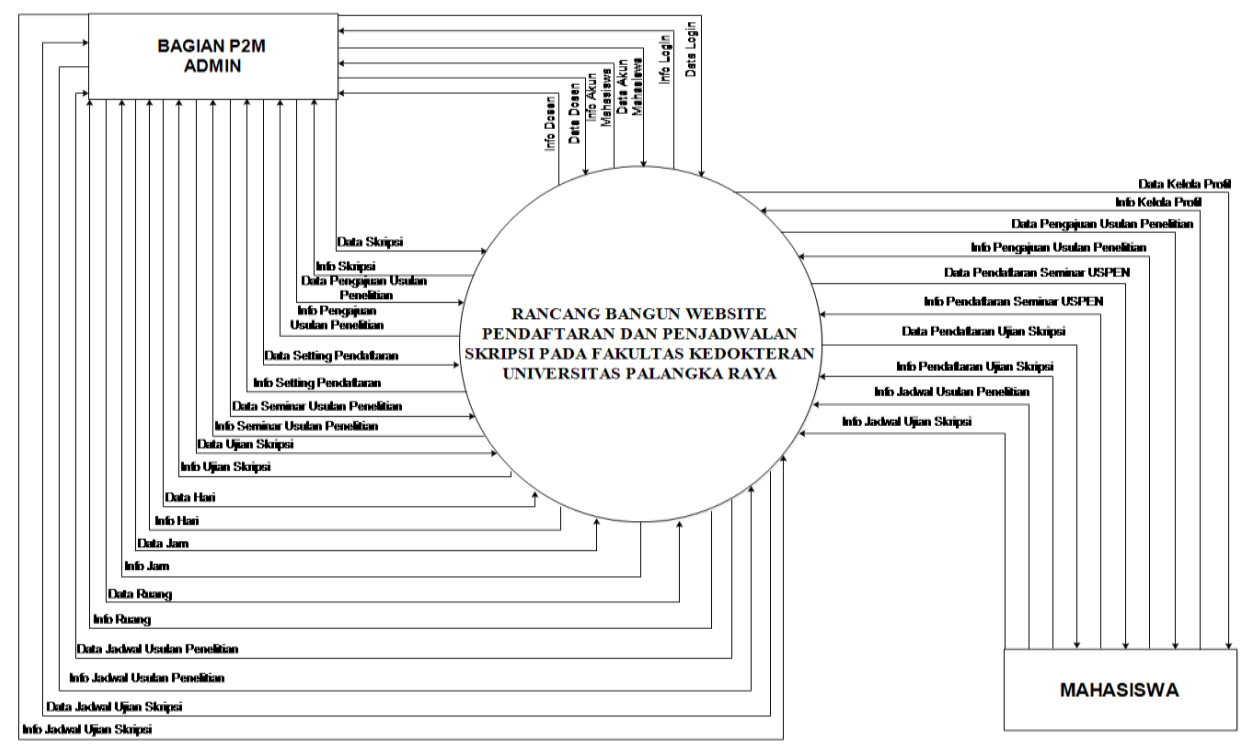

Gambar 1. Diagram Konteks 


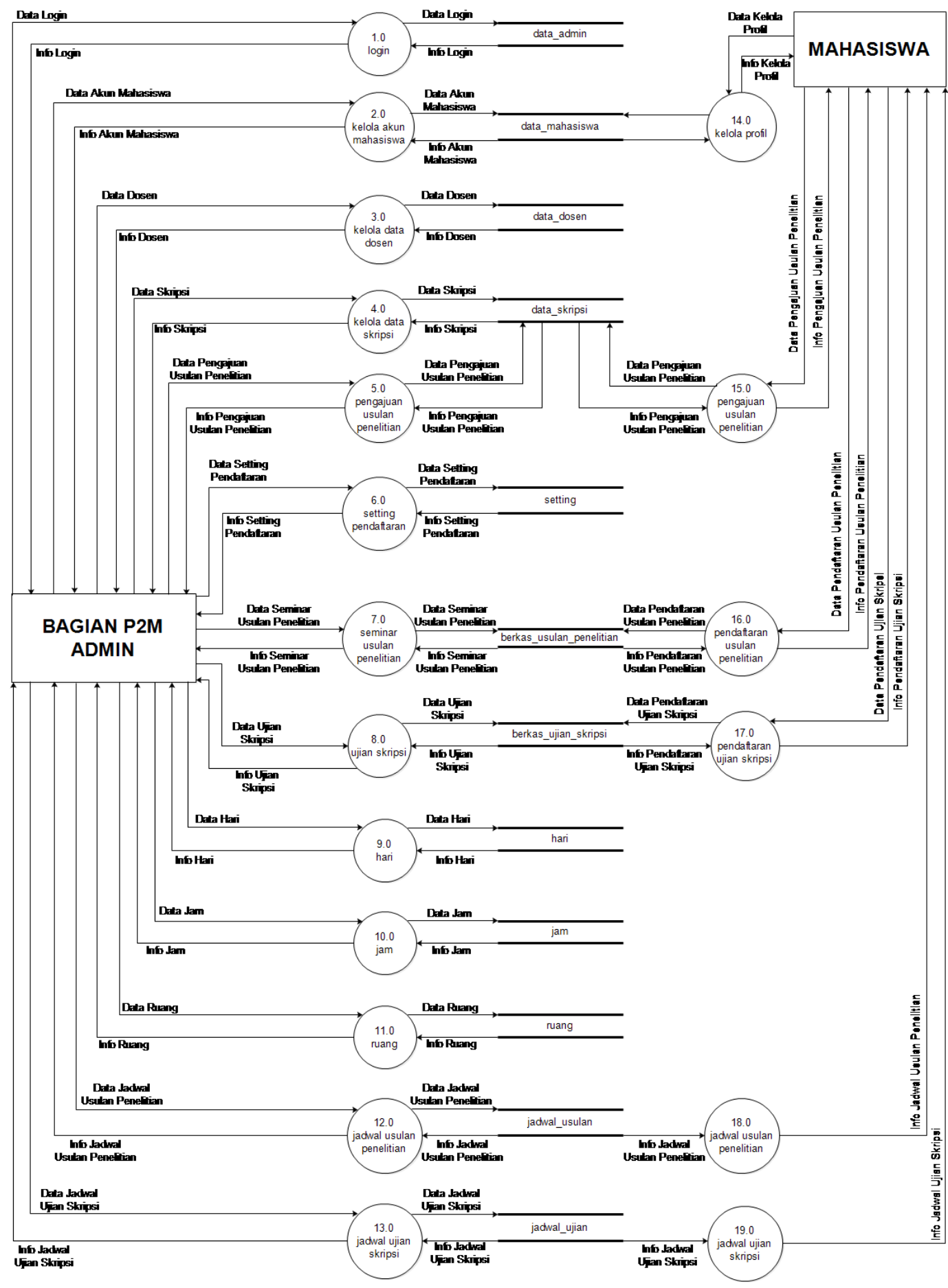

Gambar 2. DFD Level 1

Untuk pemodelan fungsional perangkat lunak ini menggunakan Entity Relationship Diagram (ERD) yang menggambarkan relasi atau keterkaitan antar tabel-tabel pada penelitian ini. ERD pada penelitian ini ditunjukkan pada gambar 3. 


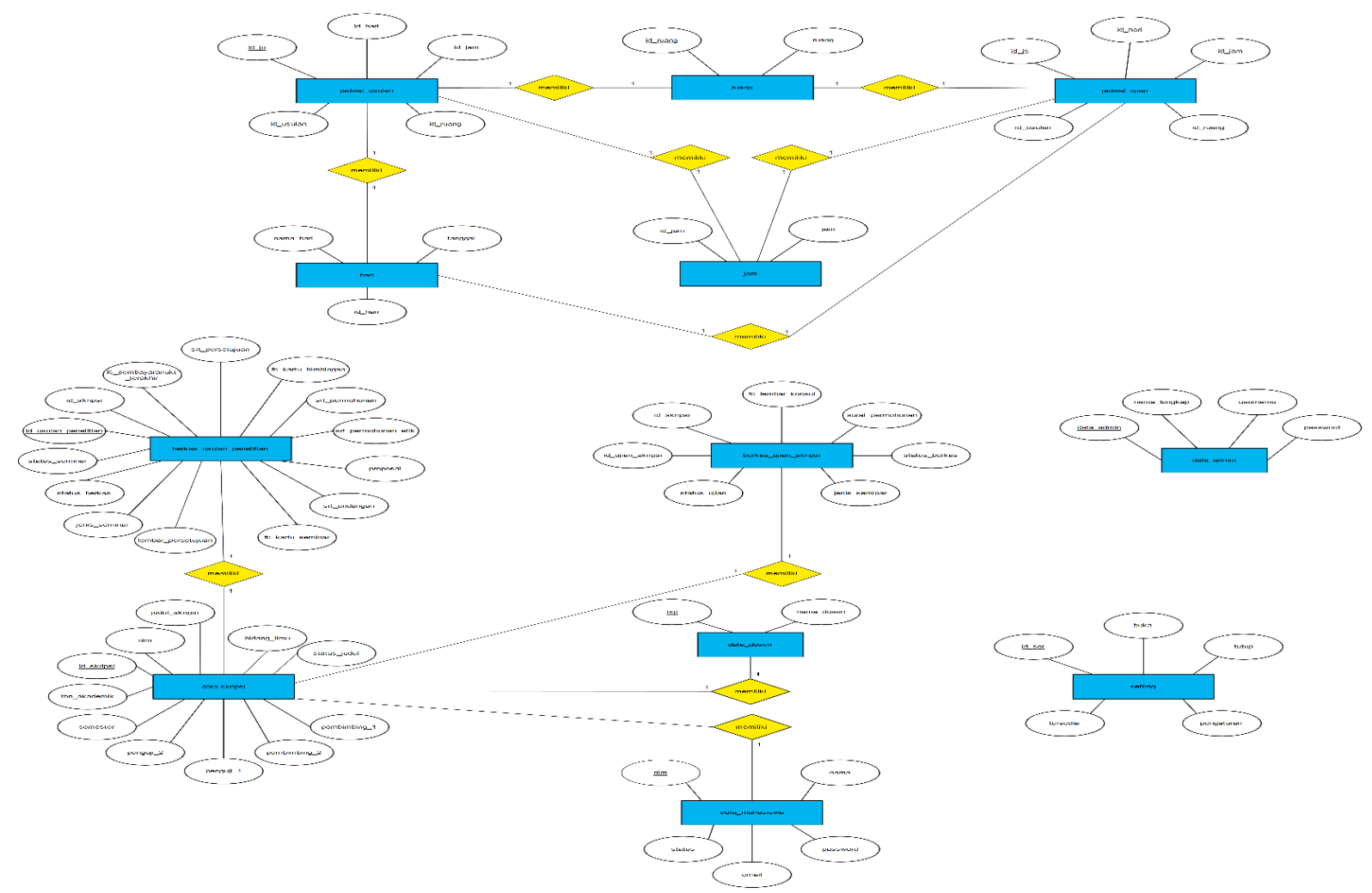

Gambar 3. ERD

\subsection{Desain}

Perancangan basis data yang digunakan dalam perangkat lunak ini dibuat dengan menggunakan MySQL. Basis data dibuat dengan nama skripsi. Tabel yang ada pada basis data skripsi yaitu tabel berkas_ujian_skripsi, tabel berkas_usulan_penelitian, tabel data_admin, tabel data_dosen, mahasiswa, tabel data_skripsi, tabel hari, tabel jadwal_ujian, tabel jadwal_usulan, tabel jam, tabel ruang, tabel setting. Untuk perancangan navigation tree dari pengguna Bagian P2M dapat dilihat pada gambar 4, dan navigation tree dari pengguna mahasiswa pada gambar 5.

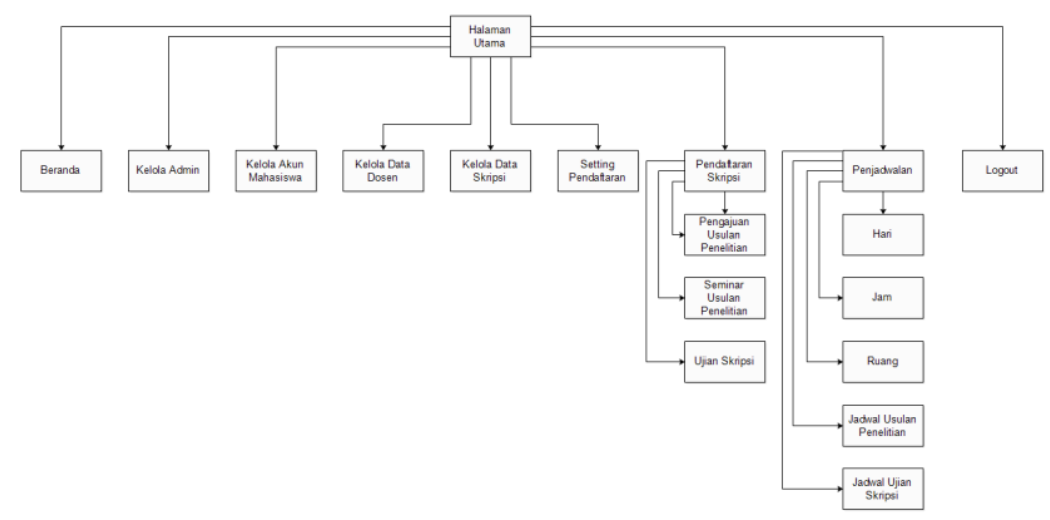

Gambar 4. Navigation Tree Bagian P2M 


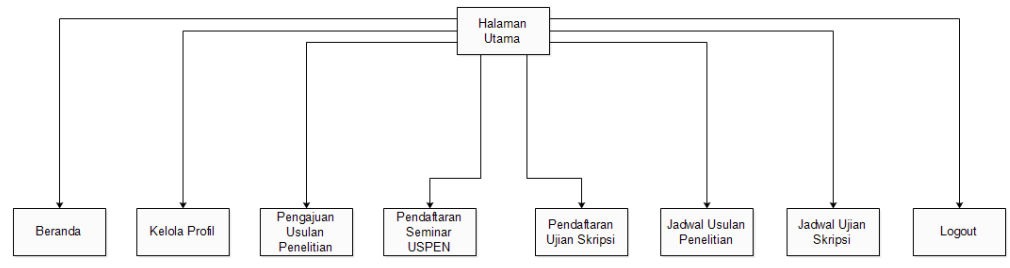

Gambar 5. Navigation Tree Mahasiswa

\subsection{Implementasi}

Implementasi perangkat lunak dilakukan sesuai dengan perancangan yang telah dilakukan pada tahap sebelumnya. Berikut ini penjelasan tentang implementasi halaman admin (Bagian P2M) dan halaman mahasiswa.

a. Pada gambar 6 menunjukkan halaman kelola admin digunakan untuk mengelola data admin. Data admin terdiri dari Nama, Username, dan Password.

b. Gambar 7 menunjukkan halaman kelola data dosen digunakan untuk mengelola data dosen. Terdapat fitur import file excel untuk memudahkan admin menambah data dosen. Selain itu admin juga dapat mengelola data mahasiswa.

c. Gambar 8 menunjukkan halaman kelola data skripsi digunakan untuk mengelola data skripsi. Data skripsi terdiri dari NIM, Nama, Judul Skripsi, Dosen Pembimbing I, Dosen Pembimbing II, Ketua Penguji, Anggota Penguji dan Tahun Akademik. Terdapat aksi edit jika ada perubahan judul skripsi.

d. Gambar 9 menunjukkan halaman setting pendaftaran skripsi digunakan untuk mengelola tanggal buka, tutup pendaftaran untuk Pengajuan Usulan Penelitian, Seminar Usulan Penelitian dan Ujian Skripsi. Serta ketersediaan ada tidaknya pendaftaran pada periode pada saat itu.

e. Gambar 10 menunjukkan halaman pendaftaran ujian skripsi, dimana Bagian P2M selaku admin dapat mengecek kelengkapan berkas mahasiswa syarat maju ujian skripsi dan menentukan status ujian setelah mahasiswa selesai melaksanakan ujian skripsi.

f. Gambar 11 menunjukkan halaman jadwal ujian skripsi, Jika di klik Button Generate Jadwal maka jadwal ujian skripsi akan ditentukan secara otomatis.

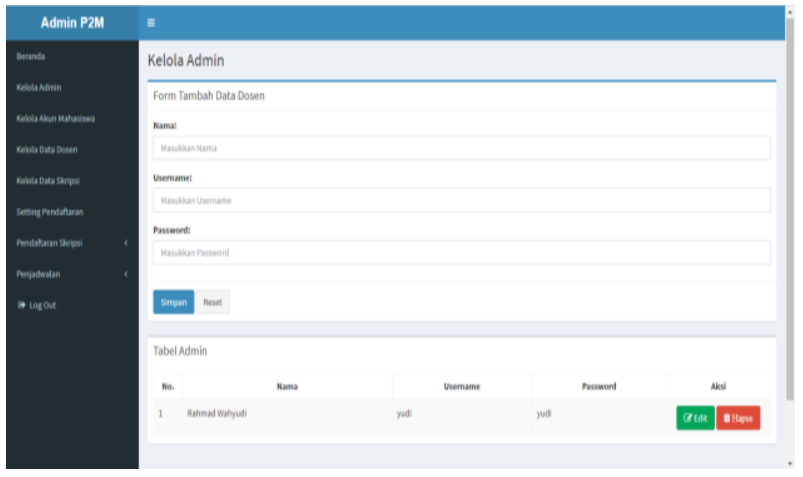

Gambar 6. Halaman Kelola Admin

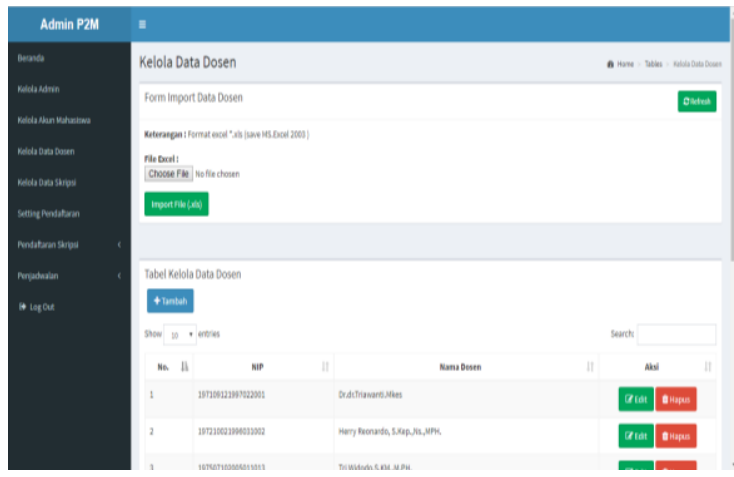

Gambar 7. Halaman Kelola Data Dosen 


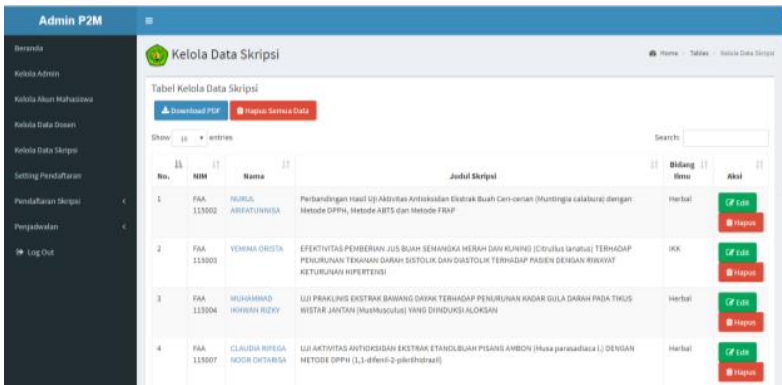

Gambar 8. Halaman Kelola Data Skripsi

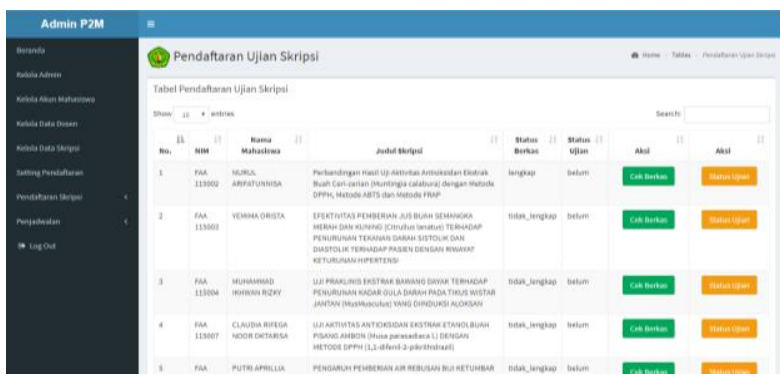

Gambar 10. Halaman Pendaftaran Ujian Skripsi

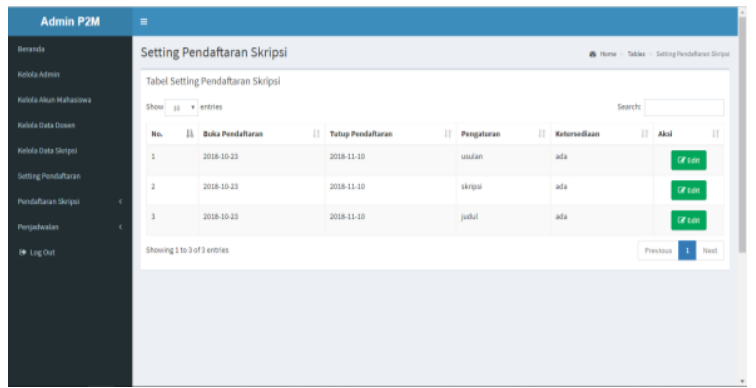

Gambar 9. Halaman Setting Pendaftaran Skripsi

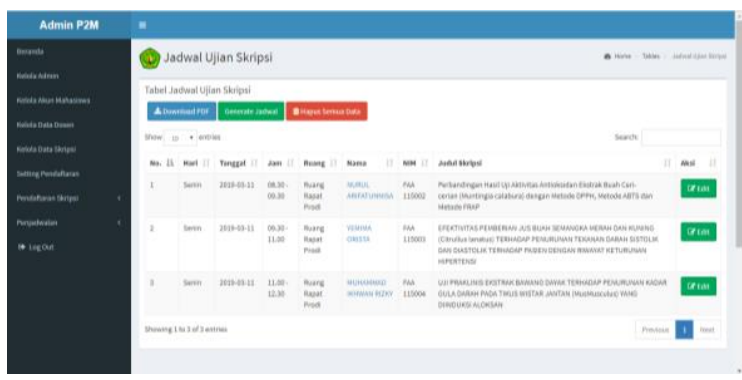

Gambar 11. Halaman Jadwal Ujian Skripsi

g. Gambar 12 menunjukkan halaman pengajuan usulan penelitian, pada halaman ini Mahasiswa mengajukan judul skripsi dan memilih topik/ bidang ilmu.

h. Gambar 13 menunjukkan halaman pendaftaran seminar USPEN. Mahasiswa tidak dapat mendaftar Seminar Usulan Penelitian jika belum mendaftarkan judul skripsi. Jika judul skripsi yang diajukan diterima maka mahasiswa diminta untuk melengkapi berkas syarat maju seminar usulan penelitian.

i. Gambar 14 menunjukkan halaman pendaftaran ujian skripsi. Mahasiswa harus mendaftarkan judul skripsi terlebih dahulu.

j. Gambar 15 menunjukkan halaman jadwal seminar usulan penelitian. merupakan halaman jadwal usulan penelitian. Mahasiswa mempunyai hak akses untuk melihat informasi terkait Jadwal Seminar Usulan Penelitian.

k. Gambar 16 menunjukkan halaman jadwal ujian skripsi. Mahasiswa mempunyai hak akses untuk melihat informasi terkait jadwal ujian skripsi.

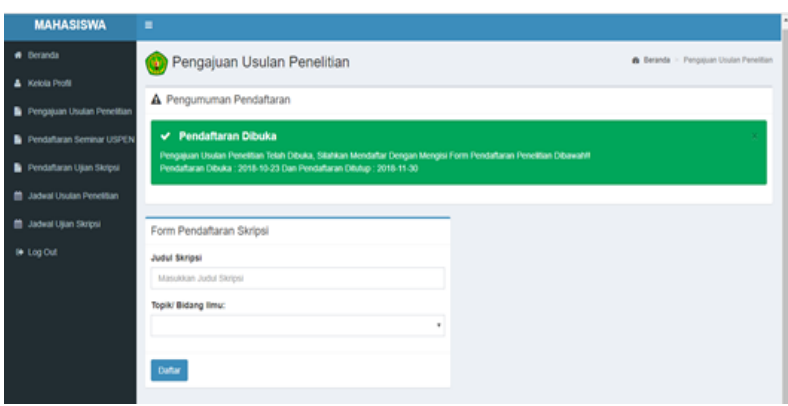

Gambar 12. Halaman Pengajuan Usulan Penelitian

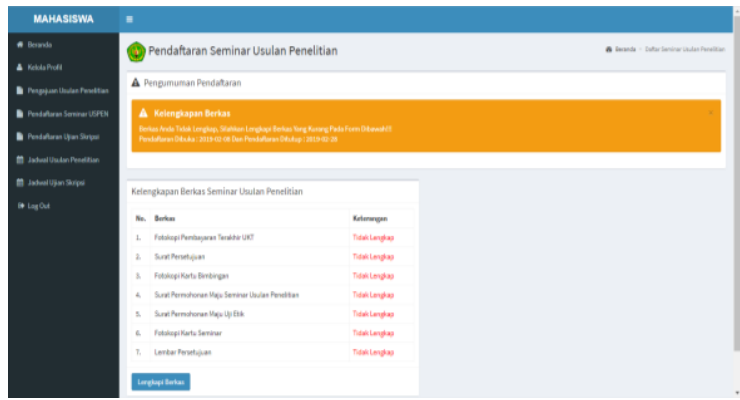

Gambar 13. Halaman Pendaftaran Seminar USPEN 


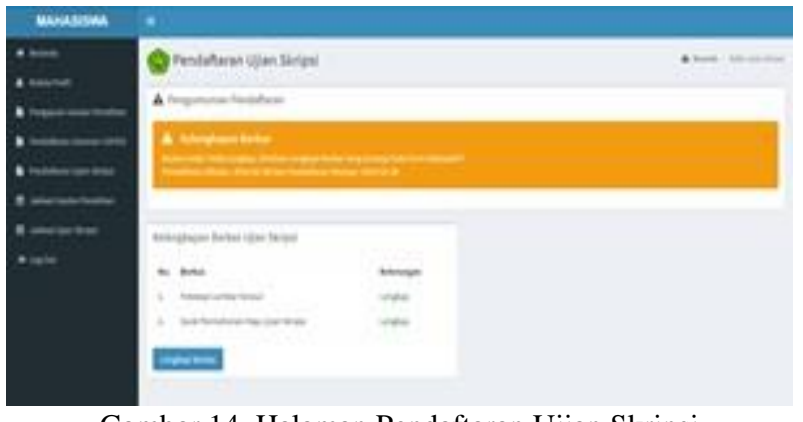

Gambar 14. Halaman Pendaftaran Ujian Skripsi

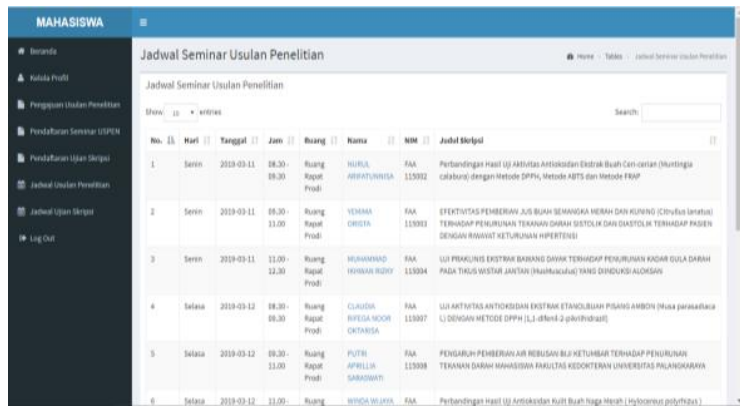

Gambar 15. Halaman Jadwal Usulan Seminar Penelitian

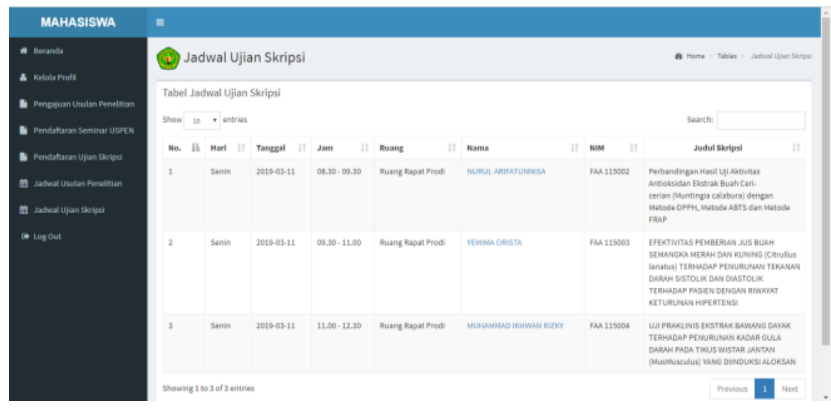

Gambar 16. Halaman Jadwal Ujian Skripsi

\subsection{Pengujian}

Pada tahap ini merupakan tahap pengujian perangkat lunak menggunakan metode blackbox testing. Metode uji coba menggunakan blackbox testing yang memfokuskan pada keperluan fungsional dari suatu perangkat lunak. Karena itu uji coba blackbox memungkinkan pengembang untuk membuat himpunan kondisi input yang akan melatih seluruh syarat-syarat fungsional suatu program. Dari hasil pengujian yang telah dilakukan tampak bahwa perangkat lunak ini dapat berjalan secara baik. Pada tabel 1 di bawah ini dapat dilihat hasil dari blackbox testing pada halaman Bagian P2M.. Pada tabel 2 di bawah ini dapat dilihat hasil dari blackbox testing pada halaman Mahasiswa.

Tabel 1. Blackbox Testing Menu Halaman Bagian P2M (Admin)

\begin{tabular}{|c|l|l|c|}
\hline No & \multicolumn{1}{|c|}{ Halaman } & \multicolumn{1}{c|}{ Proses } & Hasil \\
\hline 1 & Login admin & Menginputkan username dan password & Sesuai \\
\hline 2 & Dashboard & Menampilkan halaman utama admin & Sesuai \\
\hline 3 & Kelola admin & Menampilkan halaman kelola admin & Sesuai \\
\hline 4 & Kelola akun mahasiswa & Menampilkan halaman kelola akun mahasiswa & Sesuai \\
\hline 5 & Kelola data dosen & Menampilkan halaman kelola data dosen & Sesuai \\
\hline 6 & Kelola data skripsi & Menampilkan halaman kelola data skripsi & Sesuai \\
\hline 7 & Setting Pendaftaran & Menampilkan halaman Setting Pendaftaran & Sesuai \\
\hline 8 & Pengajuan Usulan Penelitian & $\begin{array}{l}\text { Menampilkan halaman Pengajuan Usulan } \\
\text { Penelitian }\end{array}$ & Sesuai \\
\hline 9 & $\begin{array}{l}\text { Pendaftaran Seminar Usulan } \\
\text { Penelitian }\end{array}$ & $\begin{array}{l}\text { Menampilkan halaman Pendaftaran Seminar } \\
\text { Usulan Penelitian }\end{array}$ & Sesuai \\
\hline 10 & Pendaftaran Ujian Skripsi & $\begin{array}{l}\text { Menampilkan halaman Pendaftaran Ujian } \\
\text { Skripsi }\end{array}$ & Sesuai \\
\hline 11 & Hari & Menampilkan halaman Hari & Sesuai \\
\hline 12 & Jam & Menampilkan halaman Jam & Sesuai \\
\hline 13 & Ruang & Menampilkan halaman Ruang & Sesuai \\
\hline 14 & Jadwal Usulan Penelitian & $\begin{array}{l}\text { Menampilkan halaman Jadwal Usulan } \\
\text { Penelitian }\end{array}$ & Sesuai \\
\hline
\end{tabular}




\begin{tabular}{l|l|l|l}
15 & Jadwal Ujian Skripsi & Menampilkan halaman Jadwal Ujian Skripsi & Sesuai \\
\hline
\end{tabular}

Tabel 2. Blackbox Testing Menu Halaman Mahasiswa

\begin{tabular}{|c|l|l|c|}
\hline No & Halaman & Proses & Hasil \\
\hline 1 & Login mahasiswa & Menginputkan username dan password & Sesuai \\
\hline 2 & Dashboard & Menampilkan halaman utama mahasiswa & Sesuai \\
\hline 3 & Kelola Profil & Menampilkan halaman Kelola Profil & Sesuai \\
\hline 4 & Pengajuan Usulan Penelitian & $\begin{array}{l}\text { Menampilkan halaman Pengajuan Usulan } \\
\text { Penelitian }\end{array}$ & Sesuai \\
\hline 5 & Pendaftaran Seminar USPEN & $\begin{array}{l}\text { Menampilkan halaman Pendaftaran Seminar } \\
\text { USPEN }\end{array}$ & Sesuai \\
\hline 6 & Pendaftaran Ujian Skripsi & $\begin{array}{l}\text { Menampilkan halaman Pendaftaran Ujian } \\
\text { Skripsi }\end{array}$ & Sesuai \\
\hline 7 & Jadwal Usulan Penelitian & $\begin{array}{l}\text { Menampilkan halaman Jadwal Usulan } \\
\text { Penelitian }\end{array}$ & Sesuai \\
\hline 8 & Halaman Jadwal Ujian Skripsi & $\begin{array}{l}\text { Menampilkan halaman Halaman Jadwal Ujian } \\
\text { Skripsi }\end{array}$ & Sesuai \\
\hline
\end{tabular}

\section{Kesimpulan}

Perancangan Perangkat Lunak Pendaftaran Dan Penjadwalan Ujian Skripsi Pada Fakultas Kedokteran Universitas Palangka Raya Berbasis Website ini dibuat dengan dua tahap yaitu : (1) studi pustaka, (2) menerapkan metode waterfall yang telah dimodifikasi untuk pengembangan perangkat lunak yang meliputi empat langkah yaitu analisis sistem, desain, implementasi dan pengujian. Untuk implementasi menggunakan PHP dalam membuat kode program dan Mysql sebagai database untuk menyimpan data. Selanjutnya pengujian perangkat lunak menggunakan Blackbox testing. Berdasarkan hasil pengujian yang dilakukan terhadap pengguna yaitu Bagian P2M (admin) dan mahasiswa maka dapat dilihat bahwa perangkat lunak ini dapat berjalan dengan baik.

\section{Daftar Pustaka}

[1] Agung dan Hikmah Baitul dkk. (2015). Cara Cepat Membangun Website Dari Nol. ANDI. Yogyakarta.

[2] Putra, P. B. A. A., Pranatawijaya, V. H., Widiatry, W., \& Natalius, N. (2018). Analisis dan Desain Perangkat Lunak Generate File Akun Uang Kuliah Tunggal (UKT) Universitas Palangka Raya. JURNAL TEKNOLOGI INFORMASI, 12(1), 42-49.

[3] Putra, P. B. A. A., Pranatawijaya, V. H., Widiatry, W., \& Sari, N. N. K., (2019). Pengembangan Perangkat Lunak Generate File Data Kehadiran Pegawai Universitas Palangka Raya. Anterior Jurnal,18(2), 182-189.

[4] Widiatry, W. \& Nugraha, A. (2018). RANCANG BANGUN WEBSITE E-LEARNING SMAN 1 PALANGKA RAYA. JURNAL TEKNOLOGI INFORMASI, 12(1), 57-62.

[5] Pranatawijaya, V. H., Widiatry, W., Sari, N. N. K., \& Putra, P. B. A. A. (2019). Sistem Informasi Geografis Mencari Rute Lokasi Travel Di Kota Palangka Raya Berbasis Website. JURNAL TEKNOLOGI INFORMASI, 13(1), 71-78.

[6] Widiatry, W. \& Sari, N. N. K., (2019). Rancang Bangun Website untuk Memeriksa Plagiat E-Journal Fakultas Kedokteran Universitas Palangka Raya. Jurnal CoreIT 5(2), 36-43. 
[7] Widiatry, W., Sari, N. N. K., Pranatawijaya, V. H., \& Putra, P. B. A. A. (2019). Penerapan Algoritma Levenshtein Distance Untuk Pencarian Pada Sistem Informasi Perpustakaan Fakultas Kedokteran Universitas Palangka Raya. Jurnal SAINTEKOM, 9(1), 66-82.

[8] Pressman, S. Roger. (2015). Rekayasa Perangkat Lunak: Pendekatan Praktisi Buku I. Penerbit Andi. Yogyakarta. Halaman 42.

[9] Widiatry, W. (2017). Rancang Bangun Website Sistem Informasi Praktikum Jurusan Teknik Informatika Univeritas Palangka Raya. Jurnal SAINTEKOM, 6(2), 12-24.

[10] Widiatry, W. (2020). PENGEMBANGAN APLIKASI KARTU RENCANA STUDI ONLINE PADA JURUSAN PENDIDIKAN LUAR SEKOLAH UNIVERSITAS PALANGKA RAYA. JURNAL TEKNOLOGI INFORMASI, 14(1), 83-93.

[11] Arcisphere technologies. (2012). Tutorial: The Software Development Life Cycle (SDLC). Softwarelifecyclepros.

[12] Rosa, A.S dan M. Shalahuddin. (2013). Rekayasa Perangkat Lunak Terstruktur Dan Beorientasi Objek. Penerbit Informatika. Bandung.

[13] Hars, B., Khanna, E dan Sudha. (2014). Black Box Testing based on Requirement Analysis and Design Specifications. International Journal of Computer Applications (0975 - 8887). Volume 87 No.18, (February). 